\title{
Multiple-Biomarker Approach in a Commercial Marine Scallop from San Jose gulf (Patagonia, Argentina) for Health Status Assessment
}

\author{
Julieta Sturla Lompré1 ${ }^{10} \cdot$ Gabriela Malanga ${ }^{2} \cdot$ Mónica Noemi Gil ${ }^{1} \cdot$ Erica Giarratano ${ }^{1}$
}

Received: 9 August 2019 / Accepted: 11 November 2019

๑) Springer Science+Business Media, LLC, part of Springer Nature 2019

\begin{abstract}
The health status of the commercial Tehuelche scallop Aequipecten tehuelchus from San Román and El Riacho in San José gulf (Patagonia, Argentina) was evaluated through biomarkers widely used in ecotoxicological applications. Natural levels of arsenic (As) and cadmium (Cd) were measured to determine their potential relationships with fluctuations of several oxidative stress biomarkers in the scallop. Oxidative biomarkers, such as catalase (CAT), glutathione S-transferase (GST), superoxide dismutase (SOD), metallothioneins (MT), reactive oxygen species (ROS), $\alpha$-tocopherol $(\alpha-\mathrm{T})$, and lipid peroxidation (LPO) through thiobarbituric acid reactive substances (TBARS) and lipid radical (LR*), were measured in gills, digestive gland, and muscle of Tehuelche scallop in winter (August 2015) and summer (January 2016). Levels of As and Cd and of most of the biomarkers (SOD, ROS, TBARS, and LR') showed strong seasonal variability in the three tissues. In general, the highest values were recorded in digestive gland. The Integrated Biomarker Response index indicated that the most stressed condition of A. tehuelchus was in summer in San Román. Additionally, the Integrated Biomarker Response index showed a strong relationship among tissues and $\mathrm{As}$ and $\mathrm{Cd}$ accumulation. This kind of approach could be used as an integrated tool to identify the health status of scallop A. tehuelchus from San José gulf.
\end{abstract}

Bivalve molluscs have been widely used as sentinel species to monitor environmental contamination by quantifying concentration of pollutants in soft tissues (Moschino et al. 2016). Due to their filter-feeding habit, bivalves are among the most vulnerable organisms to uptake dissolved and particulate substances, both of natural and anthropic origin (Giarratano et al. 2010; Conti et al. 2011; Maulvault et al. 2015). In this respect, they are able to incorporate ubiquitous toxic trace elements through seawater, sediment, and/ or phytoplankton, and then accumulate them in their tissues. This could eventually result in a stressing condition for the organism itself, a trophic transfer of toxics through food web

Julieta Sturla Lompré

sturla@cenpat-conicet.gob.ar

1 Centro para el Estudio de Sistemas Marinos (CESIMARCONICET), Boulevard Brown 2915 (U9120ACD), Puerto Madryn, Chubut, Argentina

2 Facultad de Farmacia y Bioquímica, Instituto de Bioquímica y Medicina Molecular (IBIMOL)-Universidad de Buenos Aires (UBA), CONICET, Fisicoquímica, Junín 956 (C1113AAD), Buenos Aires, Argentina
(Ng et al. 2005), and a risk to human health through seafood intake.

Stressful conditions, such as xenobiotic exposure, can influence the organism at the biochemical level. For example, metals are able to catalyze the formation of reactive oxygen species (ROS), which are capable of damaging proteins, lipids, and DNA (Dargay and Gately 2010). On the other hand, different cellular protection mechanisms allow detoxification of ROS before they cause oxidative damage, including the activity of antioxidant enzymes (such as superoxide dismutase, SOD and catalase, CAT), as well as nonenzymatic antioxidants (such as $\alpha$-tocopherol, $\alpha$-T). Biomarkers of defense related to detoxification mechanisms include induction of metallothioneins expression (MT) and the activity of enzyme glutathione S-transferase (GST) (Quinn et al. 2005). Oxidative stress can lead to lipid peroxidation and massive protein oxidation and degradation, causing cell injury or cell death. Lipid peroxidation (LPO) can be estimated as thiobarbituric acid reactive substances (TBARS) and lipid radicals content (LR'). The balance between free radical damage/antioxidant protection in the lipid phase is appropriately described by the ratios LR $\% \alpha-T$ 
and TBARS $/ \alpha-T$. This index assumes that higher biomarker levels indicate more damage to tissues (Lattuca et al. 2009).

Biomarkers also can be globally assessed as Integrated Biomarkers Response (IBR) index, developed as a practical and robust tool to provide a straightforward indication of the health status of bivalves and hence of the ecosystem they inhabit (Serafim et al. 2012). The biomarker approach can offer a more complete and relevant information regarding the potential impact of a pollutant on the health of the animals, constituting early warning signals in assessing biological effects of diffuse sources of pollutants (Van Der Oost et al. 1996).

In the northern coast of Patagonia (Argentina), the Tehuelche scallop Aequipecten tehuelchus is commercially exploited on small-scale, exclusively by artisanal fishers. This is an important economic resource for the small community settlement of San José gulf (SJG) in Peninsula Valdés (Soria et al. 2016). San José gulf is split longitudinally into two hydrographic domains (East and West), each one with a different pattern of water circulation. West domain is more turbulent than the East domain, and it has a low exchange of water and constant temperature during most part of the year. Otherwise, the East domain is more stagnant and the temperature responds rapidly to atmospheric temperature variations, with water stratification during the summer and vertical mixing in winter (Amoroso et al. 2011). Each study site was chosen based on the different pattern of water circulation, turbulence, and temperature variations. These differences are mainly during the summer and winter and could affect the As and Cd availabilities for the uptake by organisms. Changes in temperature, oxygen levels, and salinity can alter natural conditions through unbalance between ROS production and elimination, inducing direct effects on health status and physiological performance of marine organisms (Lushchak 2011; Nardi et al. 2018).

Although anthropogenic activities in SJG are limited to artisanal shellfish extraction activities, bioavailability of As and $\mathrm{Cd}$ has been detected in the gulf in different matrices, such as kelps, fishes, molluscs, and sediments (Gil et al. 1989, 2015; Urtubey et al. 2016; Bigatti et al. 2017; Neyro 2017). It is known that both elements may be mobilized by natural process, enhancing the environment levels. Earth crust contains As, which is released through weathering of rocks and volcanic activity (Amlund and Sloth 2011), whereas the occurrence of $\mathrm{Cd}$ may be linked to leaching from bedrock and upwelling from marine sediment deposits (Neff 2002).

The purpose of this work was to determine the health status of a natural resource of commercial importance, such as the scallop A. tehuelchus, which is naturally exposed to As and $\mathrm{Cd}$ in two coastal areas within SJG, using several biomarkers of oxidative damage in gills, digestive gland, and muscle.

\section{Materials and Methods}

\section{Sampling}

The San Jose gulf (SJG) is a small, shallow and semienclosed basin located on the north coast of Argentine Patagonia (Fig. 1). Two sampling sites were chosen in this study according to the different characteristics in each domain: El Riacho $\left(42^{\circ} 24^{\prime}\right.$ S $\left.-64^{\circ} 36^{\prime} \mathrm{W}\right)$ and San Román $\left(42^{\circ} 14^{\prime} \mathrm{S}-64^{\circ} 13^{\prime} \mathrm{W}\right)$ in the West and East domains, respectively. In both, an artisanal fishery is developed and there are no industries or important human settlements.

Samplings were performed at the same time in both sites in winter (August 2015) and summer (January 2016). Environmental parameters, such as temperature, salinity, dissolved oxygen, and $\mathrm{pH}$, were measured in situ with a multiparameter device YSI 556 MPS.

Surficial sediment samples (up to $5 \mathrm{~cm}$ depth) were collected using plastic hand-driven push tubes by scuba diving. Three composite samples of sediment were made from four tubes, placed in a plastic bag, and transported to the laboratory for storage at $-20{ }^{\circ} \mathrm{C}$ until analysis of total As and Cd. Adult Tehuelche scallops of commercial size (60 mm in shell length, Soria et al. 2016) were collected by scuba diving. The gills, digestive gland, and muscle were carefully excised, thoroughly washed with deionized water, and dried with tissue paper. For trace elements analyses, each tissue was pooled $(n=3)$ to make three composite samples and was stored in plastic bags at $-20{ }^{\circ} \mathrm{C}$. For biomarkers analyses, tissues $(n=5)$ were individually stored at $-80^{\circ} \mathrm{C}$.

\section{As and Cd Analyses}

Sediments samples and scallop's tissues were freezedried for $96 \mathrm{~h}$ and homogenized with a grinder. Samples of $0.5 \mathrm{~g}$ were digested using nitric acid, $10 \%$ diluted for sediments (U.S. EPA 2007) and concentrated for tissues (U.S. EPA 1996) in a NOVAWAVE SA microwave, using a time-temperature program of $180{ }^{\circ} \mathrm{C}$ for $10 \mathrm{~min}$. After digestion, samples were filled up to $50 \mathrm{~mL}$ with deionized water before analysis with an Agilent 720 inductively coupled plasma optical emission spectrometer (ICP-OES), with axial configuration and multi-element simultaneous detection.

Three replicates of standard reference materials of sediment (PACS-2, Marine Sediment Reference Materials for Trace Metals and other Constituents, National Research Council of Canada) and oyster tissue (NIST-SRM 1566, National Institute of Standards and Technology, Standard Reference Material) were analyzed for quality control of 


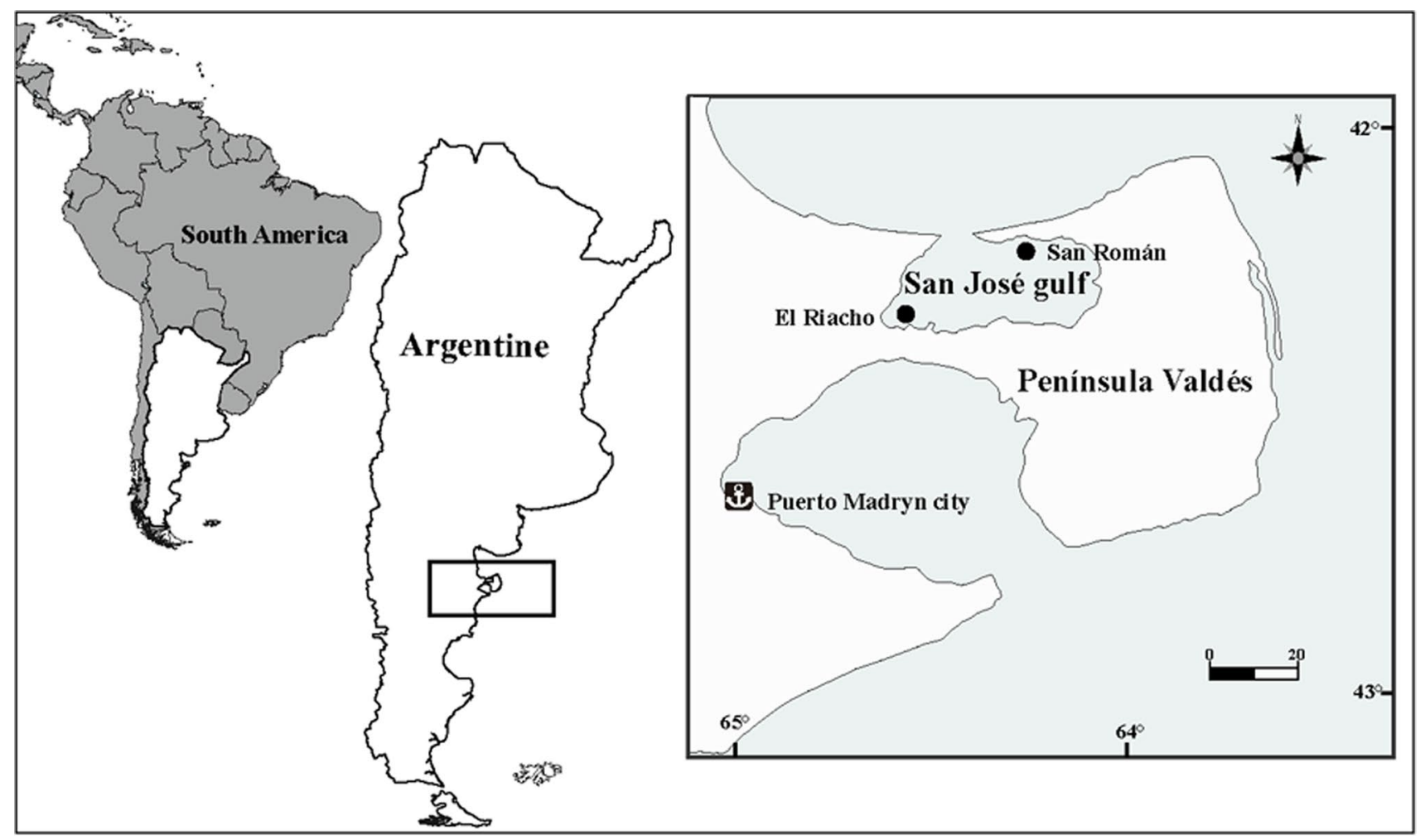

Fig. 1 Location of study sites San Román and El Riacho in San José gulf in Patagonia, Argentina

data. Precision, expressed as coefficient of variation, was $5 \%$ for As and $4 \%$ for Cd. Accuracy, expressed as percentage of recovery, was $75.7 \%$ and $114.9 \%$ for sediment PACS-2 and $90.5 \%$ and $91.1 \%$ for oyster tissue NIST-SRM 1566, for As and Cd respectively. Detection limits in dry weight basis were $0.7(\mathrm{As})$ and $0.25(\mathrm{Cd}) \mu \mathrm{g} / \mathrm{g} \mathrm{dw}$.

\section{Biochemical Analyses}

ROS were evaluated after homogenization in $100 \mathrm{mM}$ Tris-HCl buffer $\mathrm{pH} 7.75$ with $2 \mathrm{mM}$ EDTA and $5 \mathrm{mM}$ $\mathrm{MgCl}_{2}(1: 5 \mathrm{w} / \mathrm{v})$ (Gallagher et al. 1992). The homogenates were centrifuged at $4{ }^{\circ} \mathrm{C}$ for $20 \mathrm{~min}$ at $10,000 \mathrm{~g}$ and $10 \mathrm{~mL}$ of the supernatants were employed. The reaction was followed in $30 \mathrm{mM}$ HEPES, pH 7.2 buffer with $200 \mathrm{mM} \mathrm{KCl}$, and $1 \mathrm{mM} \mathrm{MgCl}{ }_{2}$. Immediately before the reading, the fluorescent probe $2^{\prime}, 7^{\prime}$ dichlorofluorescein diacetate (DCFH-DA) was added to the buffer in a final concentration of $40 \mathrm{mM}$. The reaction mixture was incubated at $40{ }^{\circ} \mathrm{C}$ during $30 \mathrm{~min}$. Thereafter, the nonfluorescent compound DCFH was oxidized by ROS to the fluorescent compound DCF, which is detected spectrofluorometrically at $\lambda \operatorname{exc}=488 \mathrm{~nm}$ and $\lambda \mathrm{em}=525 \mathrm{~nm}$ (Viarengo et al. 1999). ROS were expressed as $\mathrm{U} / \mathrm{min} / \mathrm{mg}$ prot.

For enzyme assays, samples were homogenized in a 1:3 $(\mathrm{w} / \mathrm{v})$ ratio of buffer solution containing $20 \mathrm{mM}$ Tris-Base,
$1 \mathrm{mM}$ EDTA, $1 \mathrm{mM}$ DL-dithiothreitol, $0.5 \mathrm{M}$ sucrose, $0.15 \mathrm{M} \mathrm{KCl}$, and $0.1 \mathrm{mM}$ phenylmethylsulphonyl fluoride (PMSF), with pH adjusted to 7.6 according to Bainy et al. (1996). SOD activity was measured by the inhibition of the auto-oxidation of epinephrine at $480 \mathrm{~nm}$ at $30{ }^{\circ} \mathrm{C}$ (Misra and Fridovich 1972). One unit of SOD was defined as the amount of enzyme that inhibits the rate of adrenochrome formation by $50 \%$ under the assay conditions. CAT activity was evaluated by the decomposition rate of hydrogen peroxide $\left(\mathrm{H}_{2} \mathrm{O}_{2}\right)$ at $240 \mathrm{~nm}$ as a function of the enzyme activity (Beutler 1982). One unit of CAT was defined as the amount of enzyme catalyzing the elimination of $1 \mathrm{mmol}$ $\mathrm{H}_{2} \mathrm{O}_{2}$ per minute. GST activity was determined by incubating reduced glutathione with 1-chloro-2,4-dinitrobenzene as substrate at $25^{\circ} \mathrm{C}$ and measuring the increase in absorbance at $340 \mathrm{~nm}$ (Habig et al. 1974). One unit of GST was defined as the amount of enzyme catalyzing the formation of $1 \mathrm{mmol}$ of 2,4 dinitrophenyl-S-glutathione per min. Proteins were measured by the method of Lowry et al. (1951), with bovine serum albumin as standard. Results of all enzymes were expressed as units per milligram of proteins (U/mg prot.). All determinations were done using a spectrophotometer Jasco UV/Vis 7850.

MT were analyzed according to Viarengo et al. (1997). Briefly, tissues were homogenized in $20 \mathrm{mM}$ Tris- $\mathrm{HCl}$ buffer $\mathrm{pH} 8.6(1: 3 \mathrm{w} / \mathrm{v})$, which contains $0.5 \mathrm{M}$ sucrose, 
$0.006 \mathrm{mM}$ leupeptin, $0.5 \mathrm{mM}$ PMSF and $0.01 \%$ 2-mercaptoethanol. The homogenate was centrifuged at $14,000 \mathrm{~g}$ for $40 \mathrm{~min}$ at $4{ }^{\circ} \mathrm{C}$ and the resulting supernatant was used for a subsequent two-step ethanol/chloroform precipitation $\left(6000 \mathrm{~g}\right.$ for $10 \mathrm{~min}$ at $4{ }^{\circ} \mathrm{C}$ ). After acidic ethanol/chloroform fractionation of the tissue homogenate, resulting pellets containing MT were resuspended in $5 \mathrm{mM}$ Tris $-\mathrm{HCl}$ buffer with $1 \mathrm{mM}$ EDTA pH 7 followed, by a reaction with DTNB. MT were quantified by the spectrophotometric assay using glutathione (GSH) as standard and expressed as nmol-SH/mg prot.

Content of lipid soluble antioxidant $\alpha$-T was quantified by reverse-phase HPLC with electrochemical detection using a Bioanalytical Systems LC-4C amperometric detector with a glass carbon working electrode at an applied oxidation potential of $0.6 \mathrm{~V}$. Samples of $40 \mathrm{mg}$ were homogenized in $100 \mu \mathrm{L}$ of deionized water, $15 \mu \mathrm{L}$ of $4 \%$ (w/v) butylated hydroxytoluene and $100 \mu \mathrm{L}$ of $3 \%(\mathrm{w} / \mathrm{v})$ sodium dodecyl sulfate. The samples were extracted with $200 \mu \mathrm{L}$ of methanol and $900 \mu \mathrm{L}$ of hexane. After centrifugation at $5000 \mathrm{~g}$ for $3 \mathrm{~min}$, the hexane phase was removed and evaporated to dryness under a nitrogen stream. Extracts were dissolved in methanol:ethanol (1:1) and injected for HPLC analysis (Desai 1984). D,L- $\alpha$-tocopherol (Sigma, St Louis, MO) was used as standard and the results were expressed as $\mathrm{nmol} / \mathrm{mg}$ wet weight (ww).

LPO was estimated through TBARS and LR'. TBARS were determined according to Guerra et al. (2013). Briefly, samples were homogenized in a 1:10 (w/v) saline solution $(0.9 \%)$ at $\mathrm{pH} 7.0$. Then, $0.8 \mathrm{M} \mathrm{HCl}$ in $12.5 \%$ trichloroacetic acid (TCA) was added to $250 \mu \mathrm{L}$ of homogenate prior to the addition of $1 \%$ thiobarbituric acid (TBA). Samples were incubated for $10 \mathrm{~min}$ at $100{ }^{\circ} \mathrm{C}$ in a water bath, cooled to room temperature and centrifuged at $1500 \mathrm{~g}$ for $10 \mathrm{~min}$ at $4{ }^{\circ} \mathrm{C}$. TBARS levels were measured at $535 \mathrm{~nm}$, using malondialdehyde as standard and were expressed as TBARS pmol equivalents per $\mathrm{mg}$ of protein. $\mathrm{LR}^{\bullet}$ content was determined by electron paramagnetic resonance (EPR) employing a spin trapping technique using N-t-butyl-a-phenyl nitrone (PBN). A 40 mM PBN stock solution was prepared in dimethyl sulfoxide (DMSO) immediately before use. The homogenates were prepared in DMSO-PBN (1:6 w/v). EPR spectra were obtained at room temperature using a Bruker ECS 106 spectrometer, operating at $9.81 \mathrm{GHz}$ with $50-\mathrm{kHz}$ modulation frequency. EPR instrument settings for the spin trapping experiments were as follows: microwave power, $20 \mathrm{~mW}$; modulation amplitude, $1.194 \mathrm{G}$; time constant, $81.92 \mathrm{~ms}$; scans number, 5; centre fields, $3480 \mathrm{G}$; modulation frequency, $50 \mathrm{kHz}$; and receiver gain, $2 \times 10^{4}$ (Lai et al. 1986). Quantification of $\mathrm{LR}^{*}$ content was performed according to Kotake et al. (1996) and was expressed as pmol/g ww.

\section{Data Analysis}

\section{Integrated Biomarker Response Index}

The Integrated Biomarker Response (IBR) index was performed in accordance with the protocol of Beliaeff and Burgeot (2002) with modifications by Devin et al. (2014). Briefly, the mean value $(\mathrm{X} i)$ and standard deviation $(\mathrm{SD} i)$ for each biomarker at each season and site, as well as the general mean (mi), were calculated and standardized. Subsequently, values were computed in the case of a biological effect corresponding, i.e., inhibition or activation respect the site with the lowest values of As and $\mathrm{Cd}$. Then, biomarker scores (S) were calculated as $\mathrm{S}=\mathrm{Z}+|\mathrm{Min}|$, where $\mathrm{Z} \geq 0$ and $\mid \mathrm{Minl}$ is the absolute value of all $Y$ calculated for a given biomarker (including all measurements). IBR was calculated according to the following formula:

$\mathrm{IBR}=S 1 * \frac{S 2}{2}+S 2 * \frac{S 3}{2}+\cdots S n-1 * \frac{S n}{2}+S n * \frac{S 1}{2}$

For IBR calculation six parameters were chosen through a boosted regression tree (BRT) model described in Bertrand et al. (2016). This method builds a sequence of models of increasing complexity to describe relationships between different scenarios and the predictor variables (biomarkers). The chosen biomarkers were SOD in digestive gland, GST in gills and digestive gland, MT in muscle, and TBARS in gills and digestive gland. Several IBR were calculated with $\mathrm{R}$ Studio software from the same data changing the order of the biomarkers and using the median of all the index values as the final index value (Devin et al. 2014). More details of IBR methodology can be found in some articles (Serafim et al. 2012; Devin et al. 2014; Ferreira et al. 2015; Madeira et al. 2016).

\section{Statistical Treatment}

The data are presented as the mean \pm SE. Statistical analyses were performed with Statsoft STATISTICA (v. 9.1). The variations of $\mathrm{As}$ and $\mathrm{Cd}$ levels and each oxidative stress biomarker, in the three tissues, between sites and seasons were tested by two-way ANOVA followed by a Tukey's post hoc test. Correlations between $\mathrm{As}$ and $\mathrm{Cd}$ levels and biomarkers were determined for each season with the Pearson correlation coefficient. A Kruskal-Wallis test was performed to identify IBR differences between sites and seasons. The level of significance for all tests was set at $P<0.05$. 


\section{Results and Discussion}

\section{Environmental Parameters}

The temperature of seawater in winter was $10.9 \pm 0.2{ }^{\circ} \mathrm{C}$ and in summer $17.2 \pm 1.2{ }^{\circ} \mathrm{C}$ in both sites. Salinity, dissolved oxygen, and $\mathrm{pH}$ were homogenous in both sites and seasons; the average values were $32.8 \pm 0.5 \mathrm{~g} / \mathrm{L}, 95.5 \pm 1.3 \%$, and $8.25 \pm 0.12$, respectively.

\section{As and Cd Contents}

As levels in sediments had no significant differences neither between seasons nor between sites $(3.41 \pm 0.11$ to $4.55 \pm 0.22 \mu \mathrm{g} / \mathrm{g} \mathrm{dw})$. Cd levels in all samples were below $0.50 \mu \mathrm{g} / \mathrm{g} \mathrm{dw}$. Because neither of the two elements in sediments reached the levels of the Canadian Quality Guidelines for the Protection of Aquatic Life (CCME 2002), they not represent a risk for biota.

Levels of As and Cd in tissues were around 9-18 and 2-90 $\mu \mathrm{g} / \mathrm{g} \mathrm{dw}$ respectively, being the highest values in digestive gland (Fig. 2). Other authors reported As levels around $8 \mu \mathrm{g} / \mathrm{g} \mathrm{dw}$ in soft tissues of Chlamys hastate and Pecten maximus (Phillips 1990; Meador et al. 2004) and Cd levels up to $130 \mu \mathrm{g} / \mathrm{g} \mathrm{dw}$ in digestive gland and around $14 \mu \mathrm{g} / \mathrm{g} \mathrm{dw}$ in gills of Antartic scallops (Viarengo et al. 1993).

Only in gills, levels of As and Cd showed significant interaction effect between seasons and sites with main differences in El Riacho in winter. Both elements' levels in all tissues exhibited seasonal differences at least in one study site, being the highest values those registered in the digestive gland in the summer (Fig. 2). Furthermore, digestive gland and muscle had significantly higher values in summer than in winter in contrast with the lowest values of gills in summer from El Riacho. In particular, $\mathrm{Cd}$ levels showed significant differences between seasons in the three tissues in El Riacho and only in digestive gland in both sites (Fig. 2b), being mostly higher in summer than in winter. These variations may be related to alterations in body weight and accumulation due to reproductive cycle and seasonal changes in food availability (Giarratano et al. 2011). However, the unclear temporal concentration patterns of two elements in both study sites suggest that other factors could be affecting the extent of bioaccumulation.

Comparing sites, As levels from San Román were significantly higher in summer for gills and in winter for muscle than in El Riacho. Meanwhile, Cd levels in winter were significantly lower in gills from the last place. In digestive gland, there were no significant differences between sites for both elements.

As levels were in the same order of magnitude in all samples. Conversely, $\mathrm{Cd}$ levels in digestive gland were at least 10 times higher than in the other tissues for both sites and seasons, whereas no differences were observed between gills and muscle (Fig. 2). Accordingly, other researchers found $\mathrm{Cd}$ concentrations in liver or digestive gland about tenfold or higher than concentrations in muscle (Neff 2002). Gills are one of the main pathways by which metal ions enter into aquatic organisms, being the first target organs of accumulation. In bivalves, there is an ion transfer from gills to digestive organs, and for this reason, metal(loid) concentrations are generally unstable in gills, unlike concentrations in other tissues that remain roughly constant (Zhang et al. 2015a). This observation indicates that $\mathrm{Cd}$ was probably adsorbed by the mucous coat on the gills and then was stored in digestive gland, where marine animals probably sequester metals in insoluble granules or bound to tissue proteins, such as MT (Engel and Fowler 1979; Neff 2002).

Due to the lack of anthropogenic activities in the San José gulf, the presence of both As and Cd in the studied sites should be related to natural sources and process. Contribution of As to seawater is probably related to inputs through groundwater and volcanic ashes (Farnfield et al. 2012; Alvarez and Carol 2019); meanwhile, Cd contribution may be associated to wind-related upwellings (Segovia-Zavala et al. 1998; Acha et al. 2004). Further research is required to confirm these hypotheses.
Fig. 2 Levels of As a and Cd b $(\mu \mathrm{g} / \mathrm{g} \mathrm{dw})$ in gills, digestive gland, and muscle of scallop $A$. tehuelchus from San José gulf (mean values $\pm \mathrm{SE} ; n=3$ ). Stars indicate that values are significantly different at $P<0.05$ between seasons from the same site for each tissue. Significant differences between sites are not shown
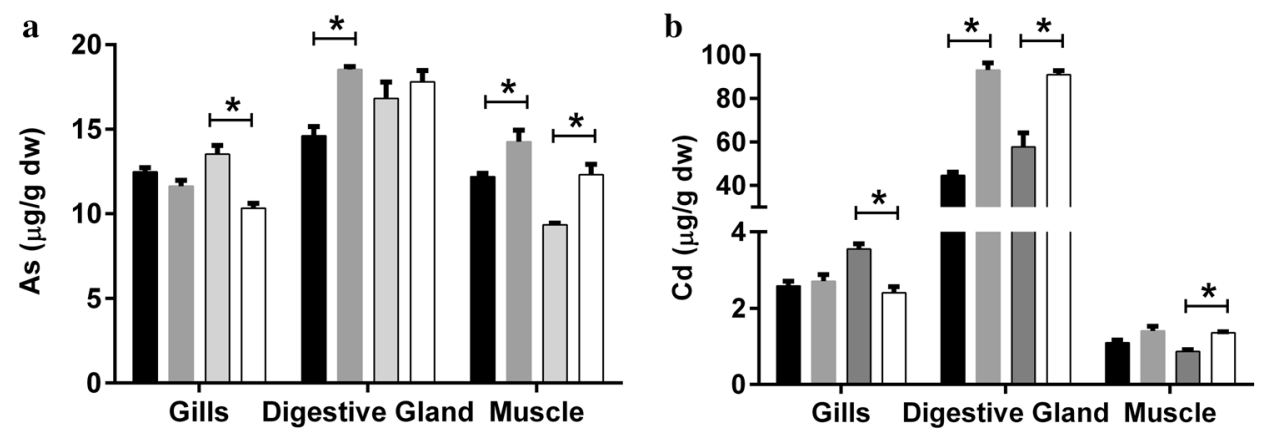

Winter San Román $\square$ Summer San Román $\square$ Winter EI Riacho $\square$ Summer EI Riacho 


\section{Biomarkers of Oxidative Stress}

Results of ROS production did not show an effect of seasonsite interaction (Table 1). ROS production in gills from San Román was significantly higher in summer than in winter (Fig. 3a). On the contrary, in digestive gland from both sites the highest ROS production was registered in winter. With respect to muscle, no seasonality was observed. The greatest ROS content was measured in digestive gland and the fewest in muscle. It is known that the exposure of aquatic organisms to metal(loid)s may increase ROS generation, which can lead to an imbalance in antioxidant defenses, enhance oxidative stress and generate lipid peroxidation (Fernández Galindo et al. 2010). This explains the high ROS production in the digestive gland, the tissue with the highest As and Cd levels.

Enzymatic activities (Fig. 3b-d) did not show a significant season-site effect (Table 1). The only exceptions were SOD in gills and digestive gland, and CAT in muscle. In these cases, the highest values were measured in winter in San Román.

The effect of seasonality on enzymatic activities was not uniform. Significantly higher SOD activities were found in winter than in summer in all tissues from San Román, but without significant differences in El Riacho (Fig. 3b). CAT activities (Fig. 3c) showed no significant differences between seasons; meanwhile, GST activity was higher in winter than in summer in digestive gland (Fig. 3d).

SOD activity in summer from both sites was significantly higher in gills and muscle than in digestive gland. The highest CAT activities were found in digestive gland (40.7-84.5 U/mg prot.), followed by gills (13.4-23.9 U/mg prot.), and muscle (2.2-3.7 U/mg prot.). In the same way, GST activity was higher in digestive gland (3.6-8.8 U/mg prot.) than in muscle (0.05-0.09 U/mg prot.) and in gills (0.01-0.07 U/mg prot.). Our results are in agreement with those reported by Moreira and Guilhermino (2005) for Mytilus galloprovincialis from a nonimpacted site in winter and summer seasons. Independently of location, GST activity in winter was the highest in digestive gland and the lowest in gills (ANOVA $P<0.05$; Tukey's test $P<0.05$ ); meanwhile in summer it was higher in digestive gland than in the other tissues (ANOVA $P<0.05$; Tukey's test $P<0.05$ ). GST has an important role as a phase II biotransformation enzyme in the detoxification and metabolism of xenobiotic compounds. GST catalyzes S-conjugation between the thiol group of GSH and electrophilic moiety in the hydrophobic and toxic substrate. Particularly, GST catalyze the bind of As, with high affinity for the thiol groups ( $\mathrm{SH}$ ) of proteins and enzymes that are crucial in cell metabolism, with GSH (Zhang et al. 2015b). The formation of methylated metabolites is a critical step in the metabolism of inorganic and organic forms of As, and it is generally assumed that the methylation pathway is directly related to the detoxification process (Gaxiola-Robles et al. 2013). Regarding the effect of Cd in GST, various mechanisms of action and contradictory effects have been reported. Some authors reported its induction through the activation of a master transcriptional regulator nuclear factor erythroid 2-related factor 2 ( $\mathrm{Nrf} 2$ ). Others reported its inhibition through direct action of the metal on the enzyme; indirectly via the production of ROS that interact directly with the enzyme, depletion of its substrate (GSH), and/or downregulation of GST genes through different mechanisms (Cunha et al. 2007).

MT content in gills and digestive gland did not show an effect of season-site interaction, in muscle; however, there was a strong effect of season-site interaction with the highest MT value in San Román in summer (11.2 \pm 1.2 nmol$\mathrm{SH} / \mathrm{mg}$ prot) (Table 1 and 2). In tissues without season-site interaction, Student's $t$ test results showed that there was no significant effect of seasonality neither of the sites.

MT content in San Roman were significantly higher in digestive gland and gills than in muscle in winter, whereas the opposite result was observed in summer. A clear tissue distribution trend was not found in this research, probably because MT synthesis may vary considerably among tissues (Zorita et al. 2007). The ability of an organism to synthesize MT can be related to many biotic and abiotic factors (Isani et al. 2000). Our results are not coincident with the expected tissue distribution, where the highest mass partition of MT is usually in the digestive gland (Raspor et al. 1999).

Despite a higher affinity of MT for Cd than for As has been proposed (Garla et al. 2016), it seems that concentrations of both elements in the digestive gland did not reach the level at which it could induce additional MT synthesis, being the existing level of MT enough to detoxify the As and $\mathrm{Cd}$ levels found in present study. The same result has been reported for mussel Mytilus galloprovincialis (Raspor et al. 2005).

$\alpha-\mathrm{T}$ act as an antioxidant defense against LPO. The $\alpha$-T content was nearly uniform in the two seasons, and it was significantly higher in digestive gland and gills than in muscle (Table 2). $\alpha$-T is one of the most important antioxidants, biosynthesized strictly by photosynthetic organisms. Hence, nonphotosynthetic organisms as bivalves must obtain them from dietary sources (Fujisawa et al. 2010). The highest values in gills and digestive gland are probably related to food intake, because gills are the first tissue in contact with food and digestive gland store and process phytoplankton rich in lipid-soluble antioxidants.

Results of LPO, estimated as TBARS and LR', are also presented in Table 2. For the three tissues and both parameters, there was no effect of season-site interaction. Regarding seasonal variations, TBARS in digestive gland from both sites and muscle from San Román were higher in winter than in summer. The highest TBARS contents were found in gills in both seasons and digestive gland in summer, 


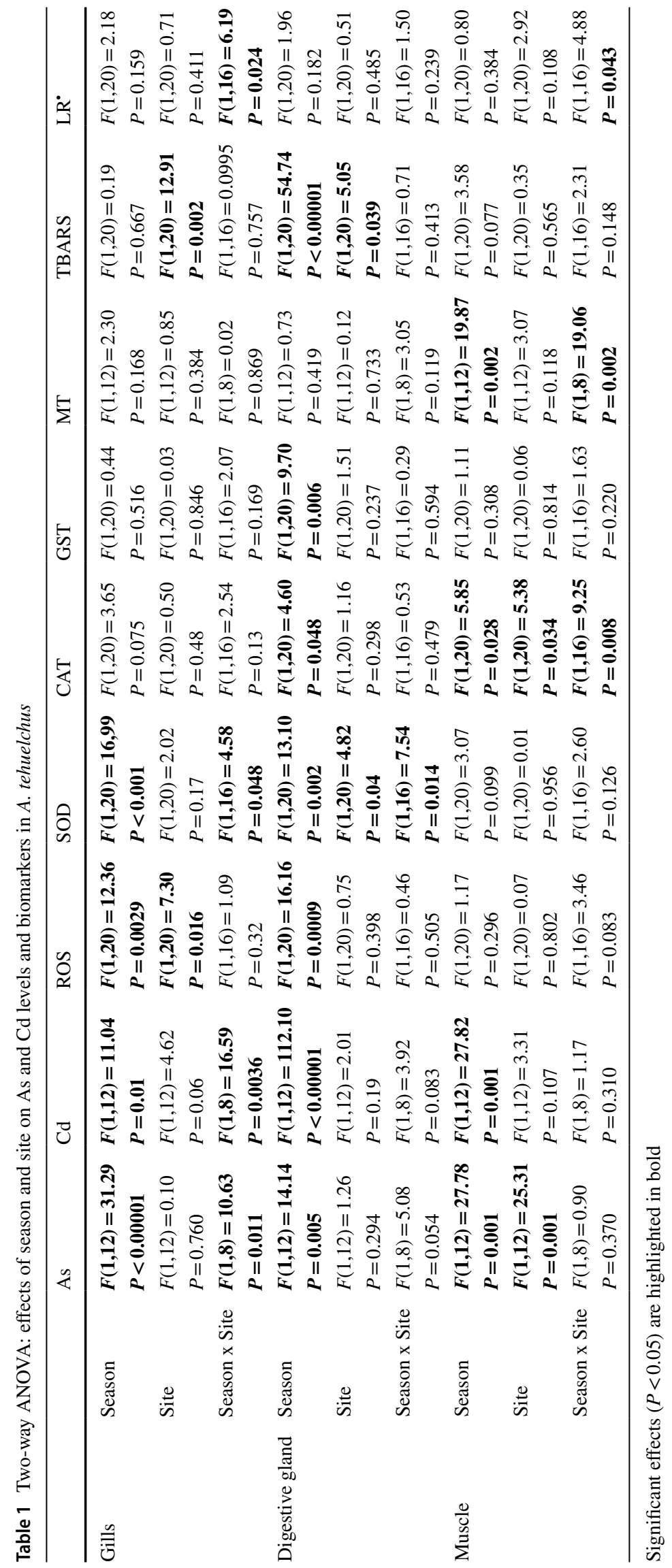


Fig. 3 Reactive oxygen species (ROS) production a and activities of superoxide dismutase (b), catalase (c), and glutathione S-transferase $\mathbf{d}$ in gills, digestive gland and muscle of $A$. tehuelchus from San Román and El Riacho in winter and summer (mean values $\pm \mathrm{SE} ; n=5$ ). Stars indicate that values are significantly different at $P<0.05$ between seasons from the same site for each tissue. Significant differences between sites are not shown
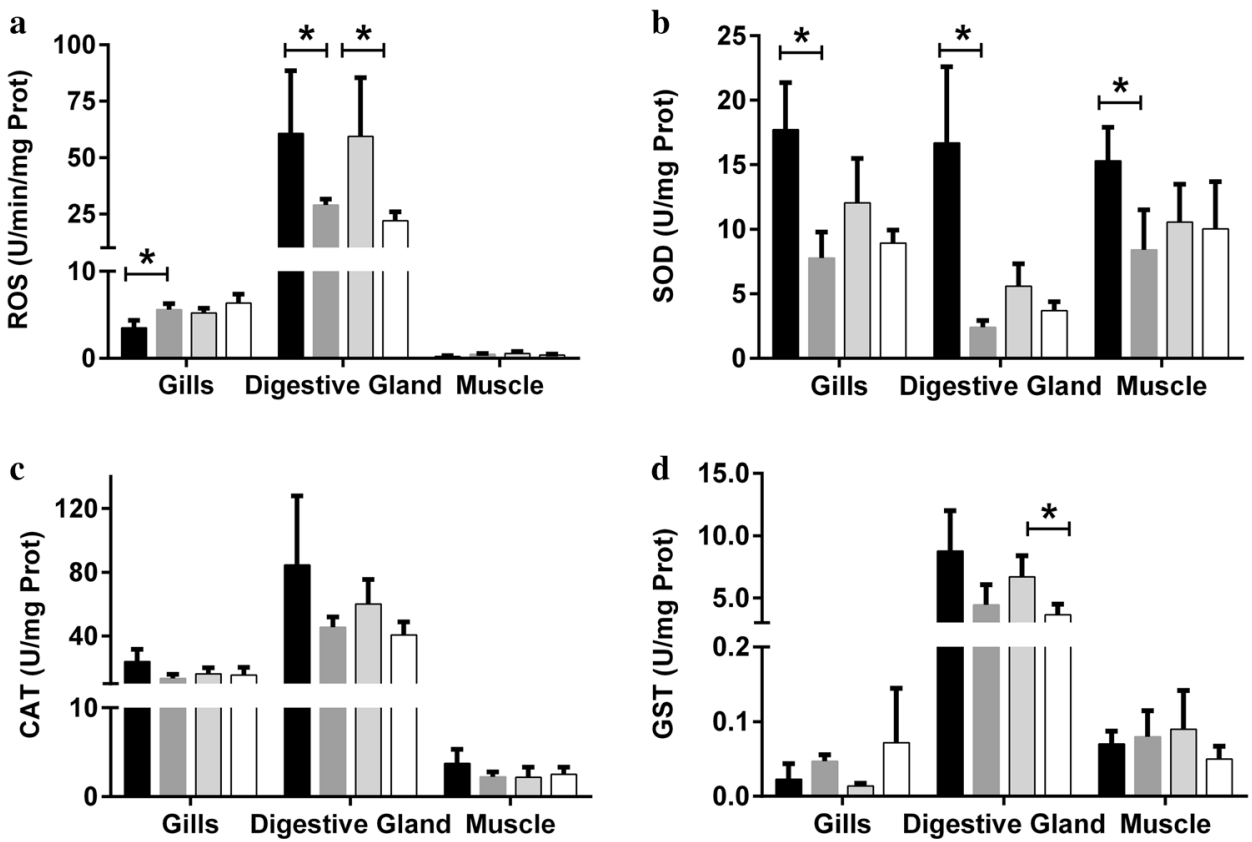

Winter San Román Summer San Román

$\square$ Winter EI Riacho $\square$ Summer EI Riacho

Table 2 Metallothionein content, $\alpha$-tocopherol, TBARS, lipid radicals, and TBARS $/ \alpha-\mathrm{T}$ and LR $\%$-T ratios in winter and summer, in both study sites for each tissue

\begin{tabular}{|c|c|c|c|c|c|c|c|}
\hline & & \multicolumn{3}{|l|}{ Winter } & \multicolumn{3}{|l|}{ Summer } \\
\hline & & Gills & Digest. Gland & Muscle & Gills & Digest. Gland & Muscle \\
\hline \multirow[t]{2}{*}{ MT (nmol-SH/mg prot) } & San Román & $5.5 \pm 0.2$ & $5.9 \pm 0.3$ & $2.1 \pm 0.8 *$ & $4.7 \pm 0.2$ & $4.8 \pm 0.4$ & $11.5 \pm 1.2^{*}$ \\
\hline & El Riacho & $5.8 \pm 0.8$ & $4.5 \pm 0.6$ & $4.9 \pm 1.5$ & $5.2 \pm 0.2$ & $5.3 \pm 0.8$ & $5.0 \pm 0.1$ \\
\hline \multirow[t]{2}{*}{$\alpha-\mathrm{T}(\mathrm{nmol} / \mathrm{mg} \mathrm{ww})$} & San Román & $44.4 \pm 11.8$ & $69.3 \pm 27.1$ & $4.6 \pm 1.1$ & $68.1 \pm 32.0$ & $77.4 \pm 28.6$ & $\mathrm{n} / \mathrm{d}$ \\
\hline & El Riacho & $53.1 \pm 12.5$ & $75.4 \pm 16.7$ & $7.3 \pm 1.9$ & $89.0 \pm 27.3$ & $38.2 \pm 6.6$ & $4.41 \pm 0.8$ \\
\hline \multirow[t]{2}{*}{ TBARS (pmol/mg ww) } & San Román & $210.0 \pm 23.5$ & $491.5 \pm 44.5^{*}$ & $273.7 \pm 52.9^{*}$ & $212.2 \pm 17.5$ & $257.8 \pm 10.8^{*}$ & $115.5 \pm 15.8 *$ \\
\hline & El Riacho & $141.7 \pm 17.7$ & $404.0 \pm 31.2 *$ & $176.0 \pm 67.0$ & $154.9 \pm 7.0$ & $218.0 \pm 12.0^{*}$ & $158.8 \pm 32.6$ \\
\hline \multirow[t]{2}{*}{$\mathrm{LR}^{\bullet}(\mathrm{pmol} / \mathrm{g} \mathrm{ww})$} & San Román & $1.7 \pm 0.2$ & $2.1 \pm 0.4$ & $0.7 \pm 0.2$ & $1.5 \pm 0.2$ & $3.8 \pm 1.0$ & $0.5 \pm 0.2$ \\
\hline & El Riacho & $1.1 \pm 0.1 *$ & $2.3 \pm 0.4$ & $0.1 \pm 0.0^{*}$ & $1.8 \pm 0.2 *$ & $2.4 \pm 0.9$ & $0.6 \pm 0.1 *$ \\
\hline TBARS/ $\alpha-T$ & San Román & $5.8 \pm 1.0$ & $11.2 \pm 6.7$ & $56.5 \pm 8.4$ & $7.8 \pm 2.6$ & $4.1 \pm 1.4$ & $\mathrm{n} / \mathrm{d}$ \\
\hline$\left(10^{-3}\right)$ & El Riacho & $4.1 \pm 1.5$ & $6.3 \pm 2.0$ & $42.5 \pm 27.5$ & $2.5 \pm 0.6$ & $6.5 \pm 1.2$ & $43.7 \pm 12.8$ \\
\hline $\mathrm{LR} * \alpha-\mathrm{T}$ & San Román & $5.6 \pm 1.9$ & $14.3 \pm 10.8$ & $16.9 \pm 3.7$ & $5.3 \pm 1.7$ & $8.6 \pm 1.9$ & $\mathrm{n} / \mathrm{d}$ \\
\hline$\left(10^{-8}\right)$ & El Riacho & $3.3 \pm 1.4$ & $9.8 \pm 4.3$ & $1.5 \pm 0.5^{*}$ & $2.7 \pm 0.5$ & $20.5 \pm 8.2$ & $21.69 \pm 13.9$ \\
\hline
\end{tabular}

Asterisk (*) indicates significant differences between seasons from the same site for each tissue. Significant differences between sites are not shown. $n / d$ no data

without seasonal differences in muscle. In digestive glands, TBARS in both sites were significantly higher in winter than in summer. On the other hand, in gills and digestive gland in summer were significantly higher in San Román than in El Riacho. LR ${ }^{\bullet}$ in all tissues had the same pattern in both sites and seasons, being the highest values measured in digestive gland, followed by gills and then muscle.

For the lipophilic compartment, the TBARS/ $\alpha-\mathrm{T}$ and $\mathrm{LR} \% \alpha-\mathrm{T}$ ratios can be understood as an indicator of the balance between free radical-dependent damage and antioxidant protection (Malanga et al. 2007). In all samples, both ratios had no significant seasonal differences, except for LR $\% \alpha-T$ in muscle from El Riacho, with the highest level in summer (Table 2). In that sense, As and Cd levels in muscle from $\mathrm{El}$ Riacho were also higher in summer than in winter. However, muscle had weak signs of damage and ROS content with respect to the other tissues. This could be explained for the lowest $\alpha$-T values in muscle due to antioxidant pigments tissue distribution closely associated with food and with other organs, such as digestive gland (Fujisawa et al. 2010). 
Regarding gills, they presented the lowest ratio values. Considering that damage and ROS production were also found in this tissue, it may be strongly suggested a high capability of antioxidant protection. On the other hand, digestive gland presented the highest tissue damage and ROS values corresponding with high $\mathrm{LR} \% \alpha$-T ratios, indicating low or not enough capability to respond to the damage in the cells. The digestive gland was the tissue with the highest As and $\mathrm{Cd}$ values, CAT and GST activities, TBARS and LR contents, and ROS.

Oxidative stress biomarkers and total levels of As and $\mathrm{Cd}$ accumulated by A. tehuelchus presented few significant correlations (Table 3). In gills, As levels were correlated negatively with $\mathrm{LR}^{\circ}$ in winter $(R=-0.93)$ and with $\alpha$-T in summer $(R=-0.84)$. The $\alpha$-T would be consumed to avoid the possible damage caused by the presence of As.

In digestive gland, As levels were correlated with GST activity $(R=-0.83)$ and MT $(R=-0.84)$ in winter. In summer Cd levels were positively correlated with TBARS $(R=0.81)$. The mechanisms by which As may affect MT induction are uncertain, but the ability of As to bind to thioland cysteine-rich proteins could perturb MT biosynthesis (Bouskill et al. 2006). The muscle exhibited significant positive correlations between As accumulation and GST $(R=0.87)$ in winter and negative correlation between $\mathrm{Cd}$ accumulation and MT $(R=-0.82)$.

Even when the differences in physical characteristics in both sites are well known (Amoroso et al. 2011), biomarkers response of scallops from San Román and El Riacho was very similar. This could be due to the animals' life history at each site, providing tolerance and adaptation to those conditions.

\section{Integrated Biomarker Response}

Effect biomarkers were integrated into an IBR index aimed to provide straight forward indication of the health status of scallops and hence of the ecosystem that they inhabit (Beliaeff and Burgeot 2002). The six biomarkers selected by BRT method were represented in the six axes of a star plot (Fig. 4a-c) and IBR values for the biomarkers chosen for each sampling site and season (Fig. 4d). Standardized biomarker responses value allowed to identify which biomarkers had the most important weight on the final IBR values. There were significant differences between sites and seasons, being the highest IBR value found in San Román in summer (7.3 \pm 0.2$)$ and the lowest in El Riacho in winter $(0.5 \pm 0.1)$.

According to Serafim et al. (2012), the IBR is capable to identify the critical seasons of the year showing that contaminants and/or environmental factors are distinct between the different seasons and influences the biomarker responses. The same authors stated that the IBR may be useful for ranking the health status of organisms in coastal areas. In that sense, IBR values (Fig. 4b) indicate that scallops from San Román and El Riacho are more impacted in summer than in winter. That is in line with the period of spawning, which implies additional stress (Soria et al. 2016), as well as with the highest values of $\mathrm{As}$ and $\mathrm{Cd}$ found in digestive gland and
Table 3 Correlation coefficients between As and Cd levels and biomarkers

\begin{tabular}{|c|c|c|c|c|c|c|}
\hline & \multicolumn{3}{|c|}{ WINTER } & \multicolumn{3}{|c|}{ SUMMER } \\
\hline & Gills & Digestive gland & Muscle & Gills & Digestive gland & Muscle \\
\hline \multicolumn{7}{|l|}{ As } \\
\hline ROS & 0.203 & 0.236 & -0.350 & -0.742 & 0.195 & 0.340 \\
\hline SOD & -0.591 & -0.694 & -0.280 & 0.405 & -0.106 & -0.144 \\
\hline CAT & 0.228 & -0.776 & 0.734 & -0.075 & 0.643 & -0.745 \\
\hline GST & 0.556 & -0.836 & 0.871 & -0.056 & 0.418 & 0.487 \\
\hline MT & 0.704 & -0.841 & -0.534 & -0.222 & -0.261 & 0.559 \\
\hline$\alpha-T$ & 0.293 & -0.055 & -0.550 & -0.842 & -0.046 & 0.466 \\
\hline TBARS & 0.655 & 0.157 & -0.055 & 0.451 & 0.302 & -0.250 \\
\hline $\mathrm{LR}^{\bullet}$ & -0.737 & 0.551 & 0.486 & -0.334 & 0.264 & -0.172 \\
\hline \multicolumn{7}{|l|}{$\mathrm{Cd}$} \\
\hline ROS & 0.571 & -0.055 & 0.286 & -0.440 & 0.346 & -0.758 \\
\hline SOD & -0.612 & -0.697 & 0.111 & 0.492 & 0.104 & 0.058 \\
\hline CAT & -0.319 & -0.626 & 0.622 & -0.051 & 0.474 & 0.771 \\
\hline GST & 0.208 & -0.654 & 0.807 & 0.019 & 0.486 & 0.478 \\
\hline MT & 0.124 & -0.439 & -0.825 & 0.154 & 0.177 & 0.377 \\
\hline$\alpha-T$ & -0.413 & 0.647 & -0.311 & -0.767 & -0.412 & -0.230 \\
\hline TBARS & 0.232 & 0.293 & -0.195 & 0.178 & 0.812 & -0.481 \\
\hline $\mathrm{LR}^{\bullet}$ & -0.931 & 0.491 & 0.178 & -0.477 & 0.227 & -0.493 \\
\hline
\end{tabular}

Numbers in bold denote significance at $P<0.05$ 
Fig. 4 a Star plot of biomarker scores of selected biomarkers (GST, SOD, and TBARS in digestive gland, MT in muscle and, TBARS and GST in gills) in San Román in winter and summer (black and grey line, respectively) and El Riacho in winter and summer (grey and black dotted line, respectively). b IBR values for each site and season. GST glutathione S-transferase, $S O D$ superoxide dismutase, TBARS thiobarbituric acid reactive substances, MT metallothioneins. Different letters indicate significant differences among each site in each season

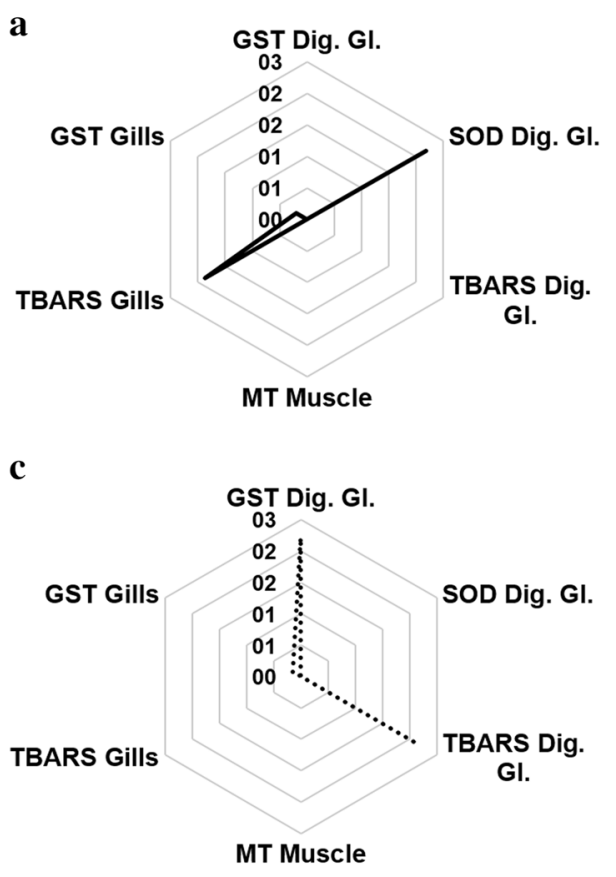

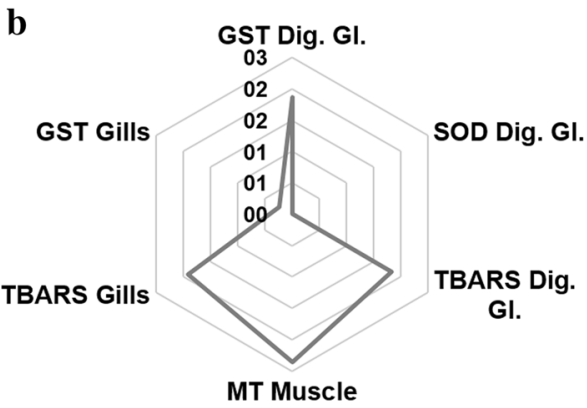

d

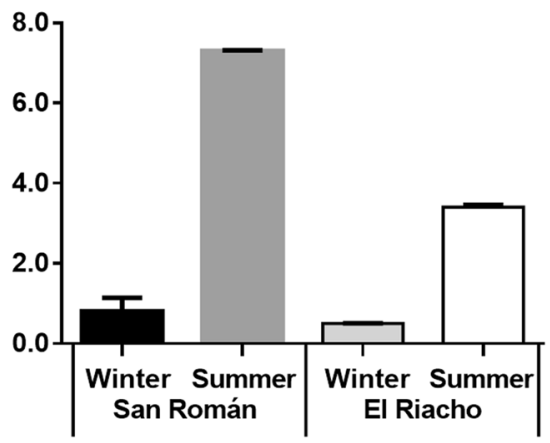

As in muscle. It has been suggested that the use of methods that combine several biological responses into a single value, allows the clarification of the results and facilitates large-scale arrangement of biomarkers in environmental monitoring (Ji et al. 2019). This index represents another valuable tool for protection of Tehuelche scallop, a natural resource of economic importance in northern coast of Argentine Patagonia.

\section{Conclusions}

The results demonstrated that each tissue of the Tehuelche scallop responds differently to xenobiotic exposure and besides depends on seasonality. In Tehuelche scallop, the digestive gland is the main tissue that accumulates As and $\mathrm{Cd}$, as well as the tissue with the highest induction of oxidative stress parameters, such as ROS, CAT, GST, TBARS, and $\alpha-T$. This study represents the first comprehensive and essential information for a proper interpretation of future ecotoxicological data and environmental monitoring programs.

Acknowledgements The authors thank the National Parks Administration and Undersecretary of Conservation and Protected Areas (Chubut Province) for their permission to carry out the present study in the Natural Reserve of Valdes Peninsula in Chubut, Argentina. The authors are grateful to Dr S. Puntarulo and her group for scientific support and technical assistance at IBIMOL. This work was supported by grants from: Conchologist of America [2016]; National University of
Patagonia San Juan Bosco [1300, 2016]; National Council for Science and Technology [CONICET PIP 0635, 2017].

\section{References}

Acha EM, Mianzan HW, Guerrero RA et al (2004) Marine fronts at the continental shelves of austral South America physical and ecological processes. J Mar Syst 44:83-105. https://doi.org/10.1016/j. jmarsys.2003.09.005

Amlund H, Sloth JJ (2011) Arsenic exposure from seafood consumption. In: Nriagu JO (ed) Encyclopedia of environmental health. Elsevier, Burlington, pp 145-149

Amoroso RO, Parma AM, Orensanz JM, Gagliardini DA (2011) Zooming the macroscope: medium-resolution remote sensing as a framework for the assessment of a small-scale fishery. ICES J Mar Sci 68:696-706. https://doi.org/10.1093/icesjms/fsq162

Bainy ACD, Saito E, Carvalho PSM, Junqueira VBC (1996) Oxidative stress in gill, erythrocytes, liver and kidney of Nile tilapia (Oreochromis niloticus) from a polluted site. Aquat Toxicol 34:151162. https://doi.org/10.1016/0166-445X(95)00036-4

Beliaeff B, Burgeot T (2002) Integrated biomarker response: a useful tool for ecological risk assessment. Environ Toxicol Chem 21:1316-1322. https://doi.org/10.1086/597420

Bertrand L, Asis R, Victoria M, Valeria M (2016) Bioaccumulation and biochemical response in South American native species exposed to zinc: boosted regression trees as novel tool for biomarkers selection. Ecol Indic 67:769-778. https://doi.org/10.1016/j.ecoli nd.2016.03.048

Beutler E (1982) Catalase. In: Beutler E (ed) Red cell metabolism: a manual of biochemical methods. Grune and Stratton Inc, New York, pp 105-106

Bigatti G, Diaz de Vivar ME, Cumplido M et al (2017) Fatty acids and contaminants in edible marine gastropods from Patagonia. J Mar Biol Assoc UK. https://doi.org/10.1017/S0025315417000625 
Bouskill NJ, Handy RD, Ford TE, Galloway TS (2006) Differentiating copper and arsenic toxicity using biochemical biomarkers in Asellus aquaticus and Dreissena polymorpha. Ecotoxicol Environ Saf 65:342-349. https://doi.org/10.1016/j.ecoen v.2005.07.027

Canadian Council of Ministers of the Environment (CCME) (2002) Canadian sediment quality guidelines for the protection of aquatic Life. Can. Environ. Qual. Guidel. Canadian E

Conti ME, Stripeikis J, Finoia MG, Tudino MB (2011) Baseline trace metals in bivalve molluscs from the Beagle Channel, Patagonia (Argentina). Ecotoxicology 20:1341-1353. https://doi. org/10.1007/s10646-011-0690-5

Cunha I, Mangas-Ramirez E, Guilhermino L (2007) Effects of copper and cadmium on cholinesterase and glutathione S-transferase activities of two marine gastropods (Monodonta lineata and Nucella lapillus). Comp Biochem Physiol C Toxicol Pharmacol 145:648-657. https://doi.org/10.1016/j.cbpc.2007.02.014

Dargay JM, Gately D (2010) World oil demand's shift toward faster growing and less price-responsive products and regions. Energy Policy 38:6261-6277. https://doi.org/10.1016/j.enpol.2010.06.014

del Alvarez MP, Carol E (2019) Geochemical occurrence of arsenic, vanadium and fluoride in groundwater of Patagonia, Argentina: sources and mobilization processes. J South Am Earth Sci 89:1-9. https://doi.org/10.1016/j.jsames.2018.10.006

Desai ID (1984) Vitamin E analysis methods for animal tissues. Methods in enzymology. Elsevier, New York, pp 138-147

Devin S, Burgeot T, Giambérini L et al (2014) The integrated biomarker response revisited: optimization to avoid misuse. Environ Sci Pollut Res 21:2448-2454. https://doi.org/10.1007/s1135 6-013-2169-9

Engel DW, Fowler BA (1979) Factors influencing cadmium accumulation and its toxicity to marine organisms. Environ Health Perspect 28:81-88

U.S. EPA (1996) Method 3052: Microwave assisted acid digestion of siliceous and organically based matrices. Washington, DC

U.S. EPA (2007) Method 3015A (SW-846): microwave assisted acid digestion of aqueous samples and extracts. Washington, DC

Farnfield HR, Marcilla AL, Ward NI (2012) Arsenic speciation and trace element analysis of the volcanic rio Agrio and the geothermal waters of Copahue, Argentina. Sci Total Environ 433:371378. https://doi.org/10.1016/j.scitotenv.2012.05.098

Fernández Galindo B, Campillo JA, Martínez-Gómez C, Benedicto J (2010) Antioxidant responses in gills of mussel (Mytilus galloprovincialis) as biomarkers of environmental stress along the Spanish Mediterranean coast. Aquat Toxicol 99:186-197. https ://doi.org/10.1016/j.aquatox.2010.04.013

Ferreira NGC, Cardoso DN, Morgado R et al (2015) Long-term exposure of the isopod Porcellionides pruinosus to nickel: costs in the energy budget and detoxification enzymes. Chemosphere 135:354-362. https://doi.org/10.1016/j.chemosphere.2015.04.025

Fujisawa A, Dunlap WC, Yamamoto Y (2010) Vitamin E protection in the biochemical adaptation of marine organisms to cold-water environments. Comp Biochem Physiol B Biochem Mol Biol 157:145-158. https://doi.org/10.1016/j.cbpb.2010.04.011

Gallagher EP, Canada AT, Digiulio RT (1992) The protective role of glutathione in chlorothalonil-induced toxicity to channel catfish. Aquat Toxicol 23:155-168. https://doi.org/10.1016/0166445x(92)90049-S

Garla R, Ganger R, Mohanty BP et al (2016) Metallothionein does not sequester arsenic(III) ions in condition of acute arsenic toxicity. Toxicology 366-367:68-73. https://doi.org/10.1016/j. tox.2016.08.008

Gaxiola-Robles R, Labrada-Martagon V, Celina Mendez-Rodriguez $\mathrm{L}$ et al (2013) Interaction between Selenium (Se) and Mercury $(\mathrm{Hg})$ affects the activity of glutathione $\mathrm{S}$-transferase in breast milk; possible relationship with fish and shellfish intake. Free
Radic Biol Med 65:S112. https://doi.org/10.1016/j.freeradbio med.2013.10.673

Giarratano E, Duarte CA, Amin OA (2010) Biomarkers and heavy metal bioaccumulation in mussels transplanted to coastal waters of the Beagle Channel. Ecotoxicol Environ Saf 73:270-279. https ://doi.org/10.1016/j.ecoenv.2009.10.009

Giarratano E, Gil MN, Malanga G (2011) Seasonal and pollutioninduced variations in biomarkers of transplanted mussels within the Beagle Channel. Mar Pollut Bull 62:1337-1344. https://doi. org/10.1016/j.marpolbul.2011.03.037

Gil MN, Sastre V, Santinelli N, Esteves JL (1989) Metal content in seston from the San José Gulf, Patagonia, Argentina. Bull Environ Contam Toxicol 43:337-341. https://doi.org/10.1007/BF017 01866

Gil MN, Torres AI, Commendatore MG et al (2015) Nutritive and xenobiotic compounds in the alien Algae Undaria pinnatifida from Argentine Patagonia. Arch Environ Contam Toxicol 68:553565. https://doi.org/10.1007/s00244-014-0090-y

Guerra C, Zenteno-Savín T, Maeda-Martínez AN et al (2013) The effect of predator exposure and reproduction on oxidative stress parameters in the Catarina scallop Argopecten ventricosus. Comp Biochem Physiol A Mol Integr Physiol 165:89-96. https://doi. org/10.1016/j.cbpa.2013.02.006

Habig WH, Pabst MJ, Jakoby WB (1974) Glutathione S-Transferases. The first enzymatic step in mercapturic acid formation. J Biol Chem 249:7130-7139

Isani G, Andreani G, Kindt M, Carpenè E (2000) Metallothioneins (MTs) in marine molluscs. Cell Mol Biol (Noisy-le-grand) 46:311-330

Ji R, Pan L, Guo R et al (2019) Using multi-integrated biomarker indexes approach to assess marine quality and health status of marine organism: a case study of Ruditapes philippinarum in Laizhou Bay, China. Environ Sci Pollut Res 2008:9916-9930. https://doi.org/10.1007/s11356-018-04082-1

Kotake Y, Tanigawa T, Tanigawa M et al (1996) Continuous monitoring of cellular nitric oxide generation by spin trapping with an iron-dithiocarbamate complex. Biochim Biophys Acta Gen Subj 1289:362-368. https://doi.org/10.1016/0304-4165(95)00172-7

Lai EK, Crosseley C, Sridhar R et al (1986) In vivo spin trapping of free radicals generated in brain, spleen, and liver during $\gamma$ radiation of mice. Arch Biochem Biophys 244:156-160

Lattuca ME, Malanga G, Aguilar Hurtado C et al (2009) Main features of the oxidative metabolism in gills and liver of Odontesthes nigricans Richardson (Pisces, Atherinopsidae). Comp Biochem Physiol B Biochem Mol Biol 154:406-411. https://doi.org/10.1016/j. cbpb.2009.08.004

Lowry OH, Rosebrough JN, Farr AL, Randall RJ (1951) Protein measurament with the folin phenol reagent. J Biol Chem 193:265-275. https://doi.org/10.1016/0304-3894(92)87011-4

Lushchak VI (2011) Environmentally induced oxidative stress in aquatic animals. Aquat Toxicol 101:13-30. https://doi. org/10.1016/j.aquatox.2010.10.006

Madeira C, Madeira D, Diniz MS et al (2016) Thermal acclimation in clownfish: an integrated biomarker response and multi-tissue experimental approach. Ecol Indic 71:280-292. https://doi. org/10.1016/j.ecolind.2016.07.009

Malanga G, Estevez MS, Calvo J et al (2007) The effect of seasonality on oxidative metabolism in Nacella (Patinigera) magellanica. Comp Biochem Physiol A Mol Integr Physiol 146:551-558. https ://doi.org/10.1016/j.cbpa.2006.01.029

Maulvault AL, Anacleto P, Barbosa V et al (2015) Toxic elements and speciation in seafood samples from different contaminated sites in Europe. Environ Res. https://doi.org/10.1016/j.envre s.2015.09.016

Meador JP, Ernest DW, Kagley A (2004) Bioaccumulation of arsenic in marine fish and invertebrates from Alaska and California. Arch 
Environ Contam Toxicol 47:223-233. https://doi.org/10.1007/ s00244-004-3035-z

Misra HP, Fridovich I (1972) The purification and properties of Superoxide Dismutase from Neurospora Crassa. J Biol Chem 247:3410-3414

Moreira SM, Guilhermino L (2005) The use of Mytilus Galloprovincialis acetylcholinesterase and glutathione S-transferases activities as biomarkers of environmental contamination along the northwest Portuguese coast. Environ Monit Assess 105:309-325. https://doi. org/10.1007/s10661-005-3854-z

Moschino V, Del Negro P, De Vittor C, Da Ros L (2016) Biomonitoring of a polluted coastal area (Bay of Muggia, Northern Adriatic Sea): a five-year study using transplanted mussels. Ecotoxicol Environ Saf 128:1-10. https://doi.org/10.1016/j.ecoenv.2016.02.006

Nardi A, Benedetti M, DErrico G et al (2018) Effects of ocean warming and acidification on accumulation and cellular responsiveness to cadmium in mussels Mytilus galloprovincialis: importance of the seasonal status. Aquat Toxicol. https://doi.org/10.1016/j.aquat ox.2018.09.009

Neff JM (2002) Cadmium in the Ocean. Bioaccumulation in marine organisms. Elsevier, New York, pp 89-102

Neyro R (2017) Bioacumulación de metales en moluscos bivalvos comestibles del Golfo San José y evaluación del efecto de la cocción. Tesis de Licenciatura, 1-40. Universidad Nacional de la Patagonia San Juan Bosco, Puerto Madryn, pp 40

Ng TYT, Amiard-Triquet C, Rainbow PS et al (2005) Physico-chemical form of trace metals accumulated by phytoplankton and their assimilation by filter-feeding invertebrates. Mar Ecol Prog Ser 299:179-191. https://doi.org/10.3354/meps299179

Phillips DJH (1990) Arsenic in aquatic organisms: a review, emphasizing chemical speciation. Aquat Toxicol 16:151-186. https://doi. org/10.1016/0166-445X(90)90036-O

Quinn B, Gagné F, Weber JP, Blaise C (2005) Ecotoxicological effects of a semi-submerged municipal dump (Castle harbour, Bermuda) on the Calico scallop Argopecten gibbus. Mar Pollut Bull 51:534544. https://doi.org/10.1016/j.marpolbul.2005.07.019

Raspor B, Erk M, Pavičić J et al (1999) Metallothionein as biomarker of mussel exposure to heavy metals. Mar Pollution 1094:151-156

Raspor B, Dragun Z, Erk M (2005) Examining the suitability of mussel digestive gland to serve as a biomonitoring target organ. Arh Hig Rada Toksikol 56:141-149

Segovia-Zavala J, Delgadillo-Hinojosa F, Alvarez-Borrego S (1998) Cadmium in the coastal upwelling area adjacent to the California-Mexico border. Estuar Coast Shelf Sci 46:475-481. https:// doi.org/10.1006/ecss.1997.0296
Serafim A, Company R, Lopes B et al (2012) Application of an integrated biomarker response index (IBR) to assess temporal variation of environmental quality in two Portuguese aquatic systems. Ecol Indic 19:215-225. https://doi.org/10.1016/j.ecoli nd.2011.08.009

Soria G, Lobo Orensanz JM, Morsán EM et al (2016) Scallops Biology, Fisheries, and Management in Argentina. In: Developments in aquaculture and fisheries science, pp 1019-1046

Urtubey B, Gil MN, Giarratano E (2016) Incorporación de arsénico por ingesta de recursos marinos patagónicos. In: Ballesteros ML (ed) IV Congreso Argentino de la Sociedad de Toxicología y Química Ambiental de Argentina, SETAC, Capítulo Argentino. M. V. Amé, Córdoba, pp 257-264

Van Der Oost R, Goksøyr A, Celander M et al (1996) Biomonitoring of aquatic pollution with feral eel (Anguilla anguilla). II. Biomarkers: pollution-induced responses. Aquat Toxicol 36:189-222. https://doi.org/10.1016/S0166-445X(96)00802-8

Viarengo A, Canesi L, Mazzucotelli A, Ponzano E (1993) Cu, Zn and $\mathrm{Cd}$ content in different tissues of the Antarctic scallop Adamussium colbecki: role of metallothionein in heavy metal homeostasis and detoxication. Mar Ecol Prog Ser 95:163-168. https://doi. org/10.3354/meps095163

Viarengo A, Ponzano E, Dondero F, Fabbri R (1997) A simple spectrophotometric method for metallothionein evaluation in marine organisms: an application to Mediterranean and Antarctic molluscs. Mar Environ Res 44:69-84. https://doi.org/10.1016/S0141 -1136(96)00103-1

Viarengo A, Burlando B, Cavaletto M et al (1999) Role of metallothionein against oxidative stress in the mussel Mytilus galloprovincialis. Am J Physiol Integr Comp Physiol 277:R1612-R1619

Zhang B, Shi Z, Wang X et al (2015a) Depuration of cadmium from blue mussel (Mytilus edulis) by hydrolysis peptides and chelating metal elements. Food Res Int 73:162-168. https://doi. org/10.1016/j.foodres.2014.12.043

Zhang W, Guo Z, Zhou Y et al (2015b) Biotransformation and detoxification of inorganic arsenic in Bombay oyster Saccostrea cucullata. Aquat Toxicol 158:33-40. https://doi.org/10.1016/j.aquat ox.2014.10.021

Zorita I, Bilbao E, Schad A et al (2007) Tissue- and cell-specific expression of metallothionein genes in cadmium- and copperexposed mussels analyzed by in situ hybridization and RT-PCR. Toxicol Appl Pharmacol 220:186-196. https://doi.org/10.1016/j. taap.2007.01.003 